\title{
'Deep is the well of the past': Reconsidering the origins of the Exodus motif in its cultural context
}

\begin{tabular}{|c|c|}
\hline \multicolumn{2}{|l|}{$\begin{array}{l}\text { Author: } \\
\text { Raik Heckl }\left.\right|^{1,2}\end{array}$} \\
\hline \multicolumn{2}{|c|}{$\begin{array}{l}\text { Affiliations: } \\
{ }^{1} \text { Department of Protestant } \\
\text { Theology, University of } \\
\text { Tuebingen, Germany }\end{array}$} \\
\hline \multicolumn{2}{|c|}{$\begin{array}{l}{ }^{2} \text { Department of Old Testment } \\
\text { Studies, University of } \\
\text { Pretoria, South Africa }\end{array}$} \\
\hline \multicolumn{2}{|c|}{$\begin{array}{l}\text { Correspondence to: } \\
\text { Raik Heckl }\end{array}$} \\
\hline \multicolumn{2}{|c|}{$\begin{array}{l}\text { Email: } \\
\text { heckl@uni-leipzig.de }\end{array}$} \\
\hline \multicolumn{2}{|c|}{$\begin{array}{l}\text { Postal address: } \\
\text { Reichelstraße 4, } 04109 \\
\text { Leipzig, Germany }\end{array}$} \\
\hline \multicolumn{2}{|c|}{$\begin{array}{l}\text { Dates: } \\
\text { Received: } 22 \text { Oct. } 2012 \\
\text { Accepted: } 18 \text { Mar. } 2013 \\
\text { Published: } 05 \text { Sept. } 2013\end{array}$} \\
\hline \multicolumn{2}{|c|}{$\begin{array}{l}\text { How to cite this article: } \\
\text { Heckl, R., 2013, "'Deep } \\
\text { is the well of the past": } \\
\text { Reconsidering the origins } \\
\text { of the Exodus motif in its } \\
\text { cultural context', Verbum } \\
\text { et Ecclesia } 34(2), \text { Art. \#806, } \\
6 \text { pages. http://dx.doi.org/ } \\
10.4102 / \text { ve.v34i2.806 }\end{array}$} \\
\hline \multicolumn{2}{|c|}{$\begin{array}{l}\text { Note: } \\
\text { Dr Raik Heckl is a research } \\
\text { associate of the Department } \\
\text { of Old Testament Studies, } \\
\text { Faculty of Theology, } \\
\text { University of Pretoria. }\end{array}$} \\
\hline \multicolumn{2}{|c|}{$\begin{array}{l}\text { Copyright: } \\
\text { (C) 2013. The Authors. } \\
\text { Licensee: AOSIS } \\
\text { OpenJournals. This work } \\
\text { is licensed under the } \\
\text { Creative Commons } \\
\text { Attribution License. }\end{array}$} \\
\hline \multicolumn{2}{|l|}{ Read online: } \\
\hline 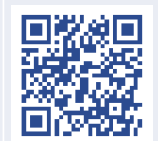 & $\begin{array}{l}\text { Scan this QR } \\
\text { code with your } \\
\text { smart phone or } \\
\text { mobile device } \\
\text { to read online. }\end{array}$ \\
\hline
\end{tabular}

The article shows, that the stories of the Patriarchs as well as the Exodus-story are allochthonous traditions of origin. We find comparable stories in the neighboring cultures of Israel. Egypt as origin of human culture was of utmost importance in the Levant. Herodotus reports a myth of origin of the Phoenicians which is of particular interest in this respect. As far as it can be seen there are affinities between this tradition and the Exodus motif from the Hebrew Bible. This raises the question if we should read the Biblical traditions as part of the comprehensive cultural context of the Levant.

\section{Introduction}

The biblical texts are today far more cautiously used for the reconstruction of the origins of Israel than 50 years ago. This is also the case in the realm of the Exodus tradition. The reason for this is that the sparse historical information is deeply interwoven with the theological intention of the biblical books and that it is connected with mythological elements. Accordingly, the confession to YHWH, who saved his people from Egypt, dominated earlier and later texts. ${ }^{1}$

We do not have extra-biblical evidence for the Exodus, ${ }^{2}$ therefore there is no means for identifying the historical remains. Even the earliest extra-biblical mentioning of Israel (1209 BC) in the stele of Pharaoh Merneptah refers only to a group of people resident in Palestine (see Weippert 2010:170) without suggesting a former relationship to Egypt. Another problem with the biblical information about the Exodus is its diversity:

- The context leading back the furthest is the reference in 1 Kings 6:1. If we take the building of the Temple under Solomon to have occurred around 950 BC, we can deduce the year 1430 BC for the Exodus. ${ }^{3}$ However, this date is suspect because it seems to be connected to the period of the existence of the first Temple and to the date of the rebuilding of the temple after the exile.

- The place names Pithom and Rameses in Exodus 1:11 refer to the second millennium. If Rameses must be identified with Pi Ramses, the verse presupposes the time of the Ramesides. ${ }^{4}$

- In Deuteromy 2-3, the conquest of the land by the Israelites starts after implying a conquest of the neighbouring peoples of Edom (Dt 2:5), Moab (Dt 2:9) and Ammon (Dt 2:19). All these peoples according to these verses seem to be of allochthonous origin. The so called 'antiquarian notices' intigrate this view in a comprehensive concept (cf. Dt 2:10, 20, 22).

For a possible dating of the Exodus, it is relevant that these notices mention the Philistines, too. According to Deuteronomy 2:23, they came from Kafthor, which is probably Crete and settled earlier than Israel in Palestine (cf. Noort 1994:37). This context would establish a dating later than the twelfth century BC. ${ }^{5}$ That this information cannot be a very late construct follows from the reference to it in Amos 9:7. ${ }^{6}$

1.Noth (1981:49) saw it as the 'primary confession (Urbekenntnis) of Israel' and as the nucleus of the Pentateuch tradition. Davies (2004:26) emphasised that there are only a few biblical books which do not refer to the Exodus.

2.On the attempt of Knauf (1988:136-137) to identify the Aramean by from an Egyptian source with Moses (cf. Davies 2004:35-36; Görg 1997:144-145; Timm 2008:92-94, 100). This source, however, is important, because it shows that persons of foreign origin could climb up to the highest level of society (cf. further Görg 1997:143-145).

3.According to the Septuagint's 440 years, it follows the year 1390 .

4.On the often suggested dating in the time of the Ramesides (cf. ibid. 2004:30). The mentioning of identifiable place names in the Bible, however, does not provide historical evidence (cf. Zenger 2012:719-720).

5.For the suggested nexus between the Exodus confession and the migration traditions of the Sea Peoples, see the summary in Strobel (1976:265-282). Because the mentioning of the Philistines in Deuteromy 2:23 as in other places does not lead back to their historical background (see Finkelstein 2003:156) it does not help to date the possible historical background of Israel's Exodus. The biblical focus on the Philistines more likely depends on their continuation as a separate ethnic entity during the Iron age. Regarding their cultural on the Philistines more likely depends on their continuation as a separate ethnic entity
development and the external influences on the Philistines see Shai (2011:128-130).

6.The mention of the Kushites in Amos 9:7 refers to the pre-exilic time of this concept, because it presupposes the dominion of the Kushites over Egypt. That, however, does not mean that the passage cannot be deuteronomistic or of exilic origin. This is even likely because of the universalism of YHWH's acting in favour of foreign peoples, which is in pre-exilic time hard to imagine. Therefore, Amos 9:7 seems to be a transformed concept of the allochthonous origin of the neighbours in the guise of Deuteronomism. It is not a word of Amos, as claimed by Schullerus (1996:58). 
Therefore, the research no longer suggests the mass exodus of the Israelites from Egypt as maintained on the basis of the biblical texts. The conclusion, however, can be more pessimistic: 'There is accordingly no real reason even to attempt to find a historical background for the events of the Exodus. ${ }^{7}$ More reluctantly, the research often assumes, following M. Noth, that the Exodus from Egypt was an experience of a small group, or more recently that it resembles 'a migration from southern Palestinian city-states' (Berlejung 2011:108). Konrad Schmid (2010) was also searching for a historical clue for the Exodus story and regarded it as a story of legitimation from the Northern Kingdom of Israel under Jeroboam I. ${ }^{8}$

This contribution does not intend to assemble old and new indications for the possible historicity of the Exodus in order to make the literary sources speak again. It intends, rather, to add more problematic aspects to the inconsistent testimonies which advise more caution in identifying the Exodus motif with concrete historical situations.

\section{The allochthonous origin as a comprehensive concept in the Hebrew Bible}

Konrad Schmid recently pleaded for the original independence of the patriarchal tradition on the one hand and the Exodus on the other hand. One of the most important reasons was the different reference made by these two traditions to the land (Schmid 2010):

If the ancestor story and the Moses/Exodus story both establish the same thing for Israel, that is, two traditions of Israelspecifically the relationship of Israel to its land (its preexisting inhabitants and its neighbors), albeit in very different ways (the one autochthonous, inclusive, and pacifistic, and the other allochthonous, exclusive, and aggressive)-then a fundamental tension between these two transmission complexes is to be expected. (pp. 147-148) $)^{9}$

Many of the peculiarities of the Exodus story and of the Patriarch story are obvious. ${ }^{10}$ However, Schmid (2010) sees the latter as a story of Israel's origin that originally was connected to the land: 'The ancestor narratives thus reflect an essentially autochthonous concept of the assimilative development of Israel's identity in its land' (Schmid 2010:111).

However, he must use literary criticism in excluding content diverging from his thesis. Thus, he sees the notes concerning Abraham's origin in Genesis 11:27-32 as 'a later construction in the wake of the needs of the Babylonian golah that is

7.This statement of N.P. Lemche is cited according to Davies (2004:27). Lemche (1996:52) assumes further that the text of the book of Exodus is mostly unhistorical.

8.Schmid (2010:128) assumes that there was 'once a literary presentation of Exodus that culminated in the legitimation of Jeroboam's rebellion'. Knauf (2008:24) holds this position in attenuated form and considers the time of Jeroboam II. At that time, it could have become part of the state ideology. On the critique of this concept, see Otto (2009:13-14).

\section{Cf. Schmid (2008:297).}

10.In addition, we must note that the Exodus account is a closed narrative, but the stories of the patriarchs are still relatively independent short accounts. Exodus 1-15 deals with the beginning of the 'history' of Israel, whilst the patriarchs in Genesis 12-50 represent the later people of Israel. only attested in P and later' (Schmid 2010:11). Nevertheless, Schmid has overlooked the fact that this passage only excerpts information and does not narrate in detail. If its priestly authors would have introduced new concepts, they would have been forced to mediate such a radical new departure to their readers. In addition, the older parts of the Jacob-Labanstory are connected to the information from Genesis 11:27-32 (cf. Carr 2011:116). So Jacob moved over to his relatives in Haran. Though Genesis 11:27-32 is part of a priestly linking text it presupposes pre-priestly information.

Of the three patriarchs, it is only Isaac who remains during his life in Palestine. The relationship to Haran, however, is also of importance for him. After all, the Jacob story is based on the kinship of Isaac's wife Rebekka. Abram/Abraham and Sarai/Sara commute from Mesopotamia via Syria to Palestine and from there to Egypt and back again. Jacob flees to Haran and, after his return to Palestine, he descended to Egypt, where he died. ${ }^{11}$ To see all these narrative elements as 'constructions in the wake of the needs of the Babylonian golah' is impossible for the reason that some of them are older traditions.

The assumption that all of them could be late post-exilic inventions fails also because of the pragmatic nature of the texts: The introduction to Joshua's farewell speech in Joshua 24:2-4, for instance, starts with the subject of the allochthonous origin of the forefathers. It aims at the acclamation of the people to serve $\mathrm{YHWH}$ alone. Indeed this text must be of late origin, but it would neither be understood nor accepted by the intended readers if they would not be aware of the traditions of a Mesopotamian origin of Abraham. ${ }^{12}$ This text presupposes known information about the ancestors, that, namely, Abraham and Jacob were liminal figures between autochthony and allochthony, between dependence and independence, between the worship of other Gods and the worship of YHWH. And, in relation to the later land of Israel, they were just not remembered as autochthonous.

These aspects enable us to see proper agreements in content between the Exodus account and the patriarch stories. Similarly as in the Joseph story, the figures of Abram and Sarai went into Egypt (Gn 12:10-20) to find salvation from starvation and since the existence of Israel in Exodus 1 is in danger, so it is during Abram's sojourn into Egypt. We also find parallel motifs in the patriarch stories and in the Moses story that show the tradition historical nexus between the two literary complexes. For instance, the juxtaposition of Moses' and Jacob's flight and the twofold use of the well motif leading to a marriage contradict the assumption of an original independence of both traditions (Gn 27 and 29; Ex 2:15-22). ${ }^{13}$

11.Under the heading 'Myths of Migration', T. Mullen (1997) investigated the patriarch stories. He notes there that, according to the coherence between Genesis and Exodus: 'It is precisely this last mythological element, migration, that provides the necessary link in the overarching narrative between the stories of the ancestors and those concerning their immediate descendants who would find themselves in need of liberation from bondage, another important motif in the development of ethnic myths' (Mullen 1997:158).

12.If the contents of the passage would be only a later invention why should it invent the polytheistic prehistory of the forefathers? Rather it presupposes the knowledge of such a polytheistic prehistory of the forefathers in order to persuade the intended readers to accept to worship YHWH alone.

13.Schmid (2010:60) mentions the affinity but does not deal with it. 
We must also keep in mind the theme of the allochthonous origin of the neighbouring people. Deuteronomy 2:4, 9, 19 presents the Edomites, the Moabites and the Ammonites as Israel's relations which only makes sense against the background of the genealogical system of Genesis. This especially shows a close connection between the ExodusConquest-story and the patriarchal tradition. ${ }^{14}$

Additionally Deuteronomy 2-3 imply the conquest of the neighbours and mentions that they got their land from $\mathrm{YHWH}$, too. In addition to the known neighbours, Deuteronomy 2-3 mentions other peoples who took their land in possession. Deuteronomy 2:23 as well as Amos 9:7 speaks of the Kafthorites. Without doubt, both references are in their current form of deuteronomistic origin. ${ }^{15}$ The concept of YHWH giving them their land, however, shows that Israel saw itself as connected or related to them and this depends on a pre-exilic religious concept which is still visible in Deuteronomy 32:8: the deity El giving his children their land and people. ${ }^{16}$ Before the background of an ongoing development of the exclusive worship of $\mathrm{YHWH}$, such concepts were reinterpreted as acts of $\mathrm{YHWH}$ in favour of the neighbouring people. It is thrilling that Amos 9:7 mentions an exodus of the Aramaeans from Kir along with the Kafthorites, who are the Philistines, and the Kushite dominion over Egypt. ${ }^{17}$ If $\mathrm{H}$. Gese is right that this Aramaean exodus is also implied in Deuteronomy 2-3 (cf. Gese 1991:119), then Amos 9 cannot be an ad hoc invention but a known tradition of the allochthonous origin of the northern neighbours. ${ }^{18}$ The allochthonous origin of Israel's ancestors and the supposed 'blood ties' with Syria are only part of a comprehensive concept of origin. The conquest of Moab, Ammon ${ }^{19}$ and Edom ${ }^{20}$ mediated by $\mathrm{YHWH}$, as mentioned in Deuteronomy 2, is directly connected to the concept of Genesis (see in this respect the coherence between Gn 11:27-32 and the following chapters). In my opinion, the enigmatic confession Deuteronomy 26:5-9 must be interpreted within the realm of this concept. The fact that Jacob is mentioned as being an Aramaean in Deuteronomy shows that in prepriestly concepts these people were seen to be closer to the Israelites than is presupposed in the Jacob stories, which show the triumph of Jacob's family over Laban the Aramaean (cf. Gn 31:1, 14-16, 19). ${ }^{21}$ Differently, the priestly genealogies

14.See Heckl $(2004: 416,440)$

15.The reference to $\mathrm{YHWH}$ giving the land to the neighbours is obviously in Deuteronomy 2-3 a deuteronomistic topos. Accordingly, this is also likely for Amos 9:7, which supports this assumption of Gese (1991:119). However, his suggestion that the Deuteronomism, which emphasised the Exodus very much, marginalises it now is only understandable if we assume the existence of an older tradition known
now to the intended readers behind it.

16.Cf. in Heckl (forthcoming 2013) the chapter 1.3.: 'Israel as Part of a Regional "Ecumene" in the Pre-Exilic Period.'

17.The opening with כוש stands in juxtaposition to the special position given to the Israelites.

18.Cf. Strobel (1976:4-5), who sees here recollections from the time of the sea people.

19.According to Knauf $(1994: 127)$ the conquest of the Ammonites here and the assumption of a former population is an invention resulting from the deuteronomistic account of Israel's conquest. Instead of this, the Ammonites in his opinion were autochthonous. I will show that such an explanation of the reference to the neighbours from Israelite religious traditions ignores an important cultural
topos in the Levant.

20.Cf. Judges 11:15-27.

21.At least Jacob takes the wealth, the family, and, indirectly, the Gods of Laban into his possession. dissociate the Aramaeans and the Israelites from each other and emphasise the independence of Israel.

As tempting as it might be to trace back seeming indications in the biblical traditions in order to find confirmation for the cultural continuity from the Canaanite city culture to the Israel and Judah of the Iron Age, the patriarch stories cannot be used in this respect. They are based in an allochthonous concept related to the concept of the Exodus. The patriarch stories together with the Exodus account assert that Israel is of allochthonous origin in its later land and had a nonsedentary prehistory in the Levant for a long time until it got its land from YHWH (cf. Thompson 1974:299).

So, it is only historically true if A. Berlejung states that, according to Deuteronomy 26:5, the Iron Age tribes of Palestine have nothing to do with the Aramaeans, but all the more to do with the inhabitants of the former Egyptian province of Canaan' (Berlejung 2011:108), because we have to assume today that "the "conquest" was thus an internal migration from the lowlands into the highlands [...] from the cities into a large number of villages' (Berlejung 2011:110). The allochthonous concepts of the strongly mythologically influenced literary traditions, however, cannot be seen synchronically with the historical and social developments of the people in their regions. It is likely that the aetiological texts explain the origin of people and cultures not on the basis of political and social changes but on the basis of allochthonous concepts. Possibly, the reasons for the use of allochthonous myths must be seen in the attempt to give legitimacy to the culture by the definition of a clear inception. The historical background of the biblical stories is hidden in the darkness of their traditional literary nature. This judgement could be valid for the Exodus tradition, too. The biblical account's pursuit of the origin of other nations supports this assumption. It also supports the fact that this view is present in the extra-biblical texts. These texts mention for example the Neo-Assyrian legend of Sargon from a mountainous region (cf. Hecker 2001:55-56) and the royal traditions of Ugarit, which did not see the origin of their kings in the city (cf. Kinet 1981:118-119) but thought, according to their traditions, that the land of their fathers lay in the south, in Bashan (Niehr 1998:573).

\section{The Phoenicians and the Syrians of Palestine according to Herodotus}

In my opinion we do have in Herodotus a relatively early external witness that in the region of Palestine such older mythical concepts of origin existed and that there are reasons to assume that the traditions of the Israelites were part of them. The texts of Hecataeus of Abdera about the Jews which will be discussed in the next chapter give some evidence for this assumption.

The Greek traditions contain many allochthonous myths of origin. It is supposed that these are recollections from historical events from the Bronze Age. ${ }^{22}$ Herodotus, writing 22.cf. Vandiver $(1991: 89,200)$ with reference to Stubbings. 
in the fifth century, after his journey to Egypt and the Levant and, therefore, temporarily and geographically near to the time and origin of the biblical tradition literature, is of utmost importance for the evaluation of the biblical traditions. He used mythological and historical information and his composition presents a mixture of both ${ }^{23}$ as do the biblical historical books also. ${ }^{24}$ Alas, the Jews are not mentioned in his books directly. ${ }^{25}$ However, the father of historiography interestingly cites a tradition about the origin of the Phoenicians that is very reminiscent of the Exodus tradition:

These (they say) came to our seas from the sea which is called Red, and having settled in the country which they still occupy, at once began to make long voyages. ${ }^{26}$

The Phoenicians, according to Herodotus, are of allochthonous origin. With the Red Sea, he means not only the Red Sea known to us, but the entire Indian Ocean (cf. Bichler 2000:20) and he saw our Red Sea as a part of it (cf. How \& Wells 1989:54). Herodotus' note depends on the antique view that the origin of the Phoenicians was in the south of Egypt in Punt, possibly in east Africa or south Arabia (cf. How \& Wells 1989:53-54). It is interesting that he also sees a connection with Egypt. According to him, the Phoenicians learned circumcision from the Egyptians and this together with the Syrians of Palestine:

The Egyptians and those who have learnt it from them are the only people who practise circumcision. ${ }^{27}$ The Phoenicians and the Syrians of Palestine acknowledge of themselves that they learnt the custom from the Egyptians. ${ }^{28}$

At this point, it must also be emphasised that the use of the antique myths of the people in the Levant by Herodotus and his followers does not lead back to their historical origins. ${ }^{29}$ However, he witnesses too a Phoenician myth origin connected to Egypt. ${ }^{30}$ In the quotation, Herodotus mentions, besides the Phoenicians, the Syrians of Palestine, who he differentiates from the other Syrians. Undoubtedly, the Jews

23. Hunter (1982:103): "It is now clear that one cannot discover in the works of Herodotus and Thucydides a distinction between historical and mythical time, and hence an opposition of human history and mythology, for both consider the mythological period a temps des hommes, a time of real, historical personages.

24.For Herodotus is valid what is generally true: 'It has always to be remembered that ancient Greek legends and myths, like the legends and myths of all ancient peoples, were not fairy stories. They were believed as historically true [...]' (Sélincourt 1962:62). He only asks questions and tries to explain inconsistencies. Cf., ibid.

25.'Die Juden kommen bei Herodot nicht vor. Herodot ging nach Tyrus, nicht nach Jerusalem. Wie für die anderen Griechen seiner und früherer Zeit waren die Phönizier für ihn eine erkennbare Einheit, auf die unter anderem die Entdeckung des Alphabets zurückging. Die Existenz der Juden scheint unter dem Begriff Palästina (Herodot, $2.104 ; 7$. 89) verborgen geblieben zu sein' [Herodotus does no refer to the Jews. Herodotus went to Tyrus, not Jerusalem. As for the other Greeks of his and earlier times the Phoenicians were a recognisable unit, to include the discovery of the alphabet declined. The existence of the Jews seems under the term Palestine (Herodotus 2 104:7 89) to have remain hidden.] (Momigliano 1988:28, [author's own translation]).

26. Herodotus I, 1 (Translation: Godley 1966:I, 3).

27. Herodotus II, 36 (Translation: Godley 1966:I, 319).

28. Herodotus II, 104 (Translation: Godley 1966:I, 393).

29.Sweeney (2008:71) undertakes this and tries to connect Phoenicia and Punt as the land of Pharaoh. He also beliefs that Punt was the historical origin of the Phoenicians.

30.Later there appears a contextualised version of the Exodus myth: Strabon mentions in Geographica XVI, 578, that a sea miracle happened in the Mediterranean Sea during the conflict between Ptolemy and Tyros (cf. Strobel 1976:277). or Israelites must belong to this group..$^{31}$ If they adopted the practice of circumcision from the Egyptians, too, we could assume a connection between the Phoenician myth of origin and the Israelites' myth. Unfortunately, he does not unfold it, because he is not interested in the outskirts of Phoenicia. ${ }^{32}$ However, it is remarkable that this Phoenician myth of origin connected to Egypt existed in the fifth century BC, and in the direct neighbourhood of Israel.

\section{The myth of the origin of people from Egypt in Hecataeus of Abdera}

Herodotus already witnesses to the huge relevance of ancient Egypt for the history of the surrounding nations. This is why Herodotus deals with the history of Egypt from the perspective of its mythological roots. He intends to find proofs for the information from Greek literature about the relationship of the Greeks to Egypt (cf. Hunter 1982:53). He is doubtless influenced by the enormous age and importance of Egyptian culture. And so he mentions, for instance, oral reports about Egyptian priests during the sojourn of Menelaus in Egypt, mentioned by Homer. He wants to show the 'Egyptian priority in discoveries, and hence their influence on Greek civilization' (Hunter 1982:53). ${ }^{33}$ Here, Herodotus follows the intentions and worldview of his time, and therewith acquires many followers in Greek and Roman literature. This is encountered again in the first Greek account about the origin of the Jews by Hecataeus of Abdera (before 300 BC).

This text about the Jews, in his book on Egypt, contains some references to the content of the Pentateuch, which cannot be discussed here. ${ }^{34}$ They are, however, connected to written sources and are interwoven with some other information about Egypt and its relevance for the beginning of other nations:

When in ancient times a pestilence arose in Egypt, the common people ascribed their troubles to the workings of a divine agency; for indeed with many strangers of all sorts dwelling in their midst and practising different rites of religion and sacrifice, their

31.Josephus directly identifies the Syrians of Palestine with the Jews, which goes too far (cf. Bichler 2000:115). It is, however, noticeable that Herodotus explicitly differentiates the two groups of Syrians. Besides, he locates the one group in the regions of the provinces of Yehud and Samaria. Cf. ibid. The enigmatic vers Deuteronomy 26:5 maintains a close connection to the Aramaeans, as Herodotus

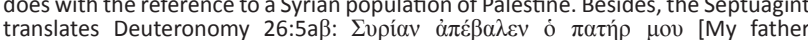
translates Deuteronor
abandoned Syria].

32.This is obvious because of the mention of offensive steles which Pharaoh Seostris allegedly erected in Palestine because of their cowardice. Cf. Herodotus II.106 (Godley 1966:I, 392-395).

33. Herodotus identifies the Greek deities with Greek heroes. According to this compare Vandiver (1991:83-92).

34.The reference to the written account at 'the end of their laws' and to Moses' role as mediator between God and the Jews is explainable only by the knowledge of an early Greek translation at least of Deuteronomy (cf. Heckl 2009:196-197). At the moment, we do not have any other knowledge of the existence of early Jewish moment, we do not have any other knowledge of the existence of early Jewish texts related to the pre-history of Israel besides the Pentateuch. The problems
in Hecataeus' account, which K. Schmid has in mind against this view (Schmid 2011:171), result only from Hecataeus' own rudimentary knowledge of Judaism and the resulting misunderstandings of the used sources. These misreadings are comparable to those Herodotus made in the use of his sources. Compare as a background of Schmid's view, his portrayal of Hecataeus in Genesis and the Moses Story, 321f. There, he uses it as evidence that the Patriarch story and the Exodus became connected only later. Schmid, ebd., 322 assumes: 'There is no mention of the ancestors and their origins in Mesopotamia. Hecataeus sets the origin of the Jews exclusively in Egypt.' However, Hecataeus states explicitly that the Jews were part of the foreign population in Egypt. 
own traditional observances in honour of the gods had fallen into disuse. Hence the natives of the land surmised that unless they removed the foreigners, their troubles would never be resolved. At once, therefore, the aliens were driven from the country, and the most outstanding and active among them banded together and, as some say, were cast ashore in Greece and certain other regions; their leaders were notable men, chief among them being Danaus and Cadmus. But the greater number was driven into what is now called Judaea, which is not far distant from Egypt and was at that time utterly uninhabited. ${ }^{35}$

At first, Hecataeus differentiated the Jews from the Egyptians and sees them as part of a non-Egyptian population in Egypt. He connects the Exodus tradition of the Israelites from Egypt with information about the origins of other nations. In his view, there was a comprehensive expulsion of strangers from Egypt. As examples he mentions Danaus ${ }^{36}$ and Cadmus. These are very important figures of the mythological prehistory of Greece. Hecataeus brings the beginnings of Israel and his rudimentary knowledge of the Jewish sources together with the beginnings of Greece, even if he sees the latter of much greater importance. ${ }^{37} \mathrm{It}$ is interesting, however, that the nexus established by Herodotus between the Phoenicians and the population of the region appears here again in the mention of Cadmus. This figure is remembered as the founder of Thebes in Greece, but he is also connected to Egypt and to Phoenicia. ${ }^{38}$ Though this is a concept, which became dominant only in the fifth century BC (Kühr 2006:93-94), there are different older myths in its background. Whether it is necessary to think with Stubbings about a connection to the Mycenaean culture is an open question (cf. Vandiver 1991:20-21). According to the leading question of this article, however, it can be noted that Egypt had been seen as the cradle of humankind and culture at least in Persian times. This topos was introduced and formulated in the realm of mythography in Greece and Phoenicia.

\section{Synthesis}

The comparison between the Exodus account and the patriarch stories and the view of the neighbours in the biblical texts and the extra-biblical origin of the myths show that allochthonous concepts of the traditions of the origins existed widespread in the Levant and in the Eastern Mediterranean. The secondary entrance into the cultivated land is obviously an old motif present in the Bible in a transformed and quasi historised form. Egypt was seen as the place of origin of the culture at least since Homer. Herodotus and Hecataeus see Egypt as the origin of the founders of nations and cities, too. Herodotus connects the origin of the Phoenicians with the

35.Translation: Walton (1984:281). Compare my own German translation, Heckl (2009:190).

36.This is already presupposed from Aeschylus: 'Aeschylus is at pains to demonstrate Stubbings, 'The Rise of the Mycenaean Civilization' quoted in Vandiver (1991:40).

37. He notices at first a group to which he assigns Danaus and Cadmus, that 'their leaders were notable men', whilst he assigns Israel to a second group: 'But the greater number were driven into what is now called Judaea.'

38.See already Herodotus II, 49-50 (cf. Godley 1966:I, 336-339), who presupposes the way of Cadmos from Egypt via Phoenicia into Greece together with the reception of the Egyptian deities. reception of the practice of circumcision from Egypt, which he also connects to the Syrians of Palestine. These connections are visible in the account of Hecataeus, too, who describes the conquest of the land by the Jews as a secondary event connected to a comprehensive expulsion of strangers from Egypt. The connection to Phoenicia is again present in the reference to Cadmus. Because the fragmentary mythology of the Phoenicians preserved by Philo of Byblos shows a relationship to Genesis $1-11^{39}$ and to pre-exilic theological concepts ${ }^{40}$, one could ask if the Exodus motif once belonged to a common preliminary stage of the Phoenician and Israelite mythology. ${ }^{41}$ It then would have served to describe the tense relationship between the cultures in the Levant and Egypt and to establish the identity of the nations on the periphery of Egypt. ${ }^{42}$ The biblical account of the Exodus and its manifold references and, of course, the different biblical attempts to locate it in history would have been only somewhat different actualisations of an older tradition and should not be confounded with their origin. The fact that, for instance, such actualisations as in Deutero-Isaiah were possible shows how deeply these traditions were ingrained into the culture of ancient Israel. They are, however, in their basis myths reformulated in centuries of literary tradition. It is therefore hardly possible to reconstruct their historical basis, if there was one. We must take care not to use the literary texts to reconstruct the early history only because they pretend to narrate events from this time. At the same time, we must take care not to search too quickly for connections between the stories and the late history. Their use in the late history possibly results only out of a late actualisation of the older traditions as an interpretation of the own fate and present circumstances.

The migration of Israel and its ancestors in the books of Genesis and Exodus is possibly connected with other origin myths from the cultures of the Levant and of Greece. This article wants to encourage seeing the Israelite tradition as part of a highly linked - one would almost like to say globalised - human culture. ${ }^{43}$ And so, there is every reason

39.Philo of Byblos witnesses to at least one Phoenician account of the beginnings of the world which is related in tradition history related to Genesis 1-11. The comparison leads J. Ebach to the following dialectic description of the relation: 'Anknüpfung und Widerspruch - Eingebunden-Sein in die Überlieferungen des alten Orients und der in ihnen thematisierten zentralen Fragen und Eigenständigkeit in theologischen und anthropologischen Aussagen' [Attachment and opposition - Integrated-being in the traditions of the ancient Orient and the key issues are addressed in them, and independence in theological and anthropological statements.] (Ebach 1979:282, [author's own translation]).

40.Cf. in Heckl (forthcoming 2013) chapter 1.3: 'Israel as Part of a Regional " Ecumene" in the Pre-Exilic Period.' Ebach (1979:69), saw the nearness between Philo (Eusebius PE 1.10.10:31-32) and Deuteronomy 32:8-9. However, he does not Philo (Eusebius PE 1.10.10:31-32) and Deuteron
think about a common mythology behind it.

41.From this perspective, the classical thesis of Franz Böhl that Israel and Canaan belonged together (cf. Böhl 1911:III) is valid even in view of the basic confession of Israel.

42.Strobel (1976:91) expresses it in a similar way, but on the basis of his identification of the Exodus with the migration of the Sea People: 'Sowohl die philistäische Vorstellung vom Auszug aus Kaphtor" als auch die israelitische Vorstellung vom "Auszug aus Ägypten" haben in gewisser Hinsicht ihren "Sitz im Leben" im Vollzug endlich errungener Freiheit, die man als Geschenk der Gottheit bewertete und zu bewahren trachtete'. 'Both the Philistine idea of 'extract from Caphtor'and the zu bewahren trachtete.' 'Both the Philistine idea of 'extract from Caphtor'and the Israelite conception of 'from Egypt' have in some respects her 'sitting in life' in the enforcement finally-won freedom, which is rated as a gift from the deity and
sought to preserve.] (Strobel 1976:91, [author's own translation]).

43.In my opinion, there is not enough evidence to relate these traditions to specific events in the past as for instance Redforth, 1992, esp. 420 does, who not only thinks that some Greek and Phoenician but also the Exodus tradition depend on the Hyksos events. 
to conclude with the wise word of Thomas Mann's Joseph novel (Mann 1948): 'Deep is the well of the past. Shall we not say it is bottomless?' (p. 3).

\section{Acknowledgements Competing interests}

The author declares that he has no financial or personal relationship(s) that may have inappropriately influenced him in writing this article.

\section{References}

Berlejung, A., 2011, 'History and Religion of Ancient Israel', in J.C. Gertz, A. Berlejung, K. Schmid \& M. Witte (eds.), Handbook of the Old Testament: An Introduction to the Literature, Religion and History of the Old Testament, pp. 59-97, T \& T Clark, London.

Bichler, R., 2000, Herodots Welt: Der Aufbau der Historie am Bild der fremden Länder und Völker, ihrer Zivilisation und ihrer Geschichte, Akademie Verlag, Berlin.

Böhl, F., 1911, Kanaanäer und Hebräer: Untersuchungen zur Vorgeschichte des Volkstums und der Religion Israels auf dem Boden Kanaans, Hinrichs, Leipzig.

Carr, D.M., 2011, The Formation of the Hebrew Bible: A New Reconstruction, Oxford University Press, New York. http://dx.doi.org/10.1093/acprof:o so/9780199742608.001.0001

Davies, G., 2004, 'Was there an Exodus?', in J. Day (ed.), In Search of Pre-Exilic Israel: Proceedings of the Oxford Old Testament seminar, pp. 23-40, T \& T Clark, London.

Ebach, J., 1979, Weltentstehung und Kulturentwicklung bei Philo von Byblos: Ein Beitrag zur Überlieferung der biblischen Urgeschichte im Rahmen des altorientalischen und antiken Schöpfungsglaubens, Kohlhammer, Stuttgart.

Gese, H., 1991, 'Das Problem von Amos 9:7', in H. Gese (ed.), Alttestamentliche Studien, pp. 116-121, Mohr, Tübingen.

Godley, A.D., 1966, Herodotus: With an English Translation, 2nd edn., William Heinemann, London.

Görg, M., 1997, Die Beziehungen zwischen dem alten Israel und Ägypten: Von den Anfängen bis zum Exil, Wissenschaftliche Buchgesellschaft, Darmstadt.

Hecker, K., 2001, 'Akkadische Mythen und Epen', in O. Kaiser (ed.), Texte aus der Umwelt des Alten Testaments. Ergänzungslieferung, pp. 34-60, Gütersloher Verlagshaus, Gütersloh. PMid:11206269

Heckl, R., 2004, Moses Vermächtnis: Kohärenz, literarische Intention und Funktion von Dtn 1-3, Evangelische Verlagsanstalt, Leipzig.

Heckl, R., 2009, Wann ist mit dem Abschluss des Pentateuchs zu rechnen?: Zu Bedeutung von Hekataios von Abdera für die Literargeschichte Israels. [When should we account for the conclusion of the Pentateuch?: About the meanin of Hekataios of Abderah for the literary history of Israel..]. Welt des Orients 39, 184-204

Heckl, R., forthcoming 2013, 'Remembering Jacob in Late Persian / Early Hellenistic Times', in D. Edelman \& E. Ben Zvi (eds.), Remembering Biblical Figures in Late Persian and Early Hellenistic Periods: Social Memory and Imagination, Oxford University Press, Oxford.

How, W.W. \& Wells, J., 1989, A Commentary on Herodotus: With Introduction and Appendixes, Clarendon Press, Oxford.
Hunter, V.J., 1982, Past and Process in Herodotus and Thucydides, Princeton University Press, Princeton.

Kinet, D., 1981, Ugarit, Geschichte und Kultur einer Stadt in der Umwelt des Alten Testamentes, Verlag Katholisches Bibelwerk, Stuttgart.

Knauf, E.A., 1988, Midian: Untersuchungen zur Geschichte Palästinas und Nordarabiens am Ende des 2. Jahrtausends v. Chr, O. Harrassowitz, Wiesbaden.

Knauf, E.A., 1994, Die Umwelt des Alten Testaments, Verlag Katholisches Bibelwerk, Stuttgart.

Knauf, E.A., 2008, Josua, Theologischer Verlag Zürich, Zürich.

Kühr, A., 2006, Als Kadmos nach Boiotien kam: Polis und Ethnos im Spiegel thebanischer Gründungsmythen, Franz Steiner, Stuttgart.

Lemche, N.P., 1996, Die Vorgeschichte Israels: Von den Anfängen bis zum Ausgang des 13. Jahrhunderts v. Chr, W. Kohlhammer, Stuttgart.

Mann, T., 1948, Joseph and his Brothers, transl. H.T. Lowe-Porter, Knopf, New York.

Momigliano, A., 1988, Die Juden in der Alten Welt, Klaus Wagenbach, Berlin.

Mullen, E.T., 1997, Ethnic Myhts and Pentateuchal Foundations: A new Approach to the Formation of the Pentateuch, Scholars press, Atlanta.

Niehr, H., 1998, Herkunft, Geschichte und Wirkungsgeschichte eines Unterweltsgotte in Ugarit, Phönizien und Israel. [Origin, history and affective history of the gods of the underwold in Ugarit, Phoenicia and Israel.]. Ugaritforschungen 30, 569-585.

Noort, E., 1994, Die Seevölker in Palästina, Kok Pharos, Kampen.

Noth, M., 1981, A History of Pentateuchal Traditions, Scholars Press, Chico.

Otto, E., 2009, 'Die Geburt des Mose: Die Mose-Figur als Gegenentwurf zur neuassyrischen Königsideologie im 7. Jh. v. Chr', in E. Otto (ed.), Die Tora: Studien zum Pentateuch, pp. 9-45, Harrassowitz, Wiesbaden.

Schmid, K., 2008, Literaturgeschichte des Alten Testaments: Eine Einführung, 1st edn., Wissenschafliche Buchgesellschaft, Darmstadt.

Schmid, K., 2010, Genesis and the Moses Story: Israel's Dual Origins in the Hebrew Bible, (orig. German: 1999), Eisenbrauns, Winona Lake.

Schmid, K., 2011, Schriftgelehrte Traditionsliteratur: Fallstudien zur innerbiblischen Schriftauslegung im Alten Testament, Mohr Siebeck, Tübingen.

Schullerus, K., 1996, Überlegungen zur Redaktionsgeschichte des Amosbuches anhand von Am 9. [Considerations editorial history book of Amos on the basis of Am 9.]. Biblische Notizen 85, 56-69.

Shai, I., 2011,'Philistia and the Philistines in the Iron Age IIA', Zeitschrift des Deutschen Palästinavereins 127, 119-134.

Sélincourt, A. de, 1962, The World of Herodotus, Seeker \& Warburg, London.

Strobel, A., 1976, Der spätbronzezeitliche Seevölkersturm: E. Forschungsüberblick mit Folgerungen zur bibl. Exodusthematik, 1st edn., de Gruyter, Berlin.

Sweeney, E.J., 2008, The genesis of Israel and Egypt, Algora Publishing, New York.

Timm, S., 2008, Der Tod des Staatsfeindes. Neues zu B3j. [The death of the public enemy. News from B3j.]. Vetus Testamentum 58, 87-100. http://dx.doi. org/10.1163/156853308X246379

Thompson, T.L., 1974, The Historicity of the Patriarchal Narratives: The Quest for the Historical Abraham, de Gruyter, Berlin.

Vandiver, E., 1991, Heroes in Herodotus: The Interaction of Myth and History, P. Lang, Frankfurt.

Walton, F.R., 1984, Diodorus of Sicily, Harvard University Press, Cambridge.

Weippert, M., 2010, Historisches Textbuch zum Alten Testament, Vandenhoeck \& Ruprecht, Göttingen. PMid:20225081

Zenger, E., 2012, Einleitung in das Alte Testament. Achte, vollständig überarbeitete Auflage, herausgegeben von Christian Frevel, Kohlhammer, Stuttgart. 